\title{
INVESTIGATING THE IMPACT OF JURY SENTENCING RECOMMENDATIONS USING PROCEDURAL JUSTICE THEORY
}

\author{
Gianni Ribeiro* and Emma Antrobus**
}

Public confidence in the criminal justice system is critical for the system to function effectively. Two studies investigated the impact of jury sentencing recommendations on public confidence using procedural justice theory. The first study $(\mathrm{N}=80)$ manipulated the presence of jury involvement in sentencing (voice present versus voice absent) and the punitiveness of the minimum nonparole period (more punitive versus less punitive) to examine whether giving juries a "voice" - a key element of procedural justice — would increase public confidence in the courts, as well as perceptions of fairness and legitimacy. Contrary to predictions, results revealed that a more punitive sentence led to increased perceptions of legitimacy, which was associated with higher confidence. The second study $(\mathrm{N}=60)$ examined whether manipulating the Judge's agreement with the jury's recommendation—as well as the Judge's reason for disagreement - would elicit the "frustration effect," leading to a decrease in confidence and perceptions of fairness and legitimacy. There was no evidence to suggest that the frustration effect was present. Results of both studies could suggest that jury sentencing recommendations may not effectively increase public

*Gianni Ribeiro is a PhD student at the School of Psychology, The University of Queensland. Her recent research focuses on jurors' understanding and interpretation of forensic expert testimony. Correspondence concerning this article should be addressed to Gianni Ribeiro, School of Psychology, The University of Queensland, St Lucia, QLD 4072. Email: gianni.ribeiro@uqconnect.edu.au.

**Emma Antrobus is a research fellow at the School of Social Science, The University of Queensland, St Lucia, QLD 4072, Australia. She has a background in social psychology and has interests in the legitimacy of social agencies, crime prevention, and child protection. Her recent research focuses on randomized controlled trials examining the impact of police behavior and legitimacy, and interventions for young people at risk.

New Criminal Law Review, Vol. 20, Number 4, pps 535-568. ISSN 1933-4192, electronic ISSN I933-4206. (C) 20I7 by The Regents of the University of California. All rights reserved. Please direct all requests for permission to photocopy or reproduce article content through the University of California Press's Reprints and Permissions web page, http://www.ucpress.edu/ journals.php? $\mathrm{p}=$ reprints. DOI: https://doi.org/IO.I525/nclr.20I7.20.4.535. 
confidence and perceptions of fairness and legitimacy in the courts, however alternate explanations are discussed.

Keywords: procedural justice, jury sentencing, legitimacy, voice

\section{INTRODUCTION}

Ensuring an adequate level of public confidence in the criminal justice system has become a prime concern for many Western nations, as public confidence and trust is crucial for the system to function effectively (Roberts, 2007). Not surprisingly then, most legal reforms are aimed at improving public confidence to ensure that the justice system is wellfunctioning (Hough \& Roberts, 2004; NSWLRC, 2006; Roberts \& Indermaur, 2009). One method to improve public confidence suggests involving juries in the sentencing of offenders by having the jury recommend the sentence-commonly referred to as jury sentencing recommendations. Jury sentencing recommendations are currently practiced in some parts of North America (Iontcheva, 2003) and have been recently proposed in at least one Australian state (Andrews \& Pakula, 20I3). Despite this, no known empirical evidence exists to evaluate the impact of jury sentencing recommendations on public confidence.

As they are representatives of the public, providing the jury with the opportunity to engage in decision-making processes is a way of giving the public a voice. The concept of "voice" (Hirschman, 1970, 1974) is a key element in procedural justice theory (Goodman-Delahunty, 20Io; Thibaut \& Walker, 1975; Tyler, 2003; Tyler \& Lind, 1988) and is known to have positive effects on confidence (Rottman, 2005; Tyler, 200I) as well as perceptions of fairness and legitimacy (Mazerolle, Antrobus, Bennett, \& Tyler, 2013; Tyler, 2003). However, in certain circumstances where a person's voice is not perceived to be adequately considered or heard, voice may elicit a "frustration effect" (Folger, 1977), resulting in negative effects on confidence, as well as on perceptions of fairness and legitimacy (Avery \& Quiñones, 2002; Ulbig, 2008). The current research aimed to investigate the effects of jury sentencing recommendations on public confidence, as well as perceptions of fairness and legitimacy of the courts. 


\section{A. Public Confidence and Punitiveness}

Public confidence is of central importance to the criminal justice system as low confidence may decrease the public's willingness to obey the law (Robinson \& Darley, 1997), report known crimes to police (Jones \& Weatherburn, 20IO), or participate in trials as a witness or juror (Hough $\&$ Roberts, 2004; Mackenzie et al., 2012). Public confidence in the criminal justice system has become a prime concern to many governments, many of whom are seeking to understand the factors that may influence public confidence. Recent research has highlighted that, compared to some European nations, Australia, the United States, Canada, and the United Kingdom all have issues with public confidence to varying degrees (Chaplin, Flatley, \& Smith, 20II; Roberts, 2007; Sourcebook of Criminal Justice Statistics, 20I2; Statistics Canada, 2003). For example, the European Values Study, conducted in 1999-2000, examined public confidence in the criminal justice system in 36 countries worldwide (Roberts, 2007). Australia was ranked 27 th out of the 36 countries, with only 35 percent of respondents having a high level of confidence in their criminal justice system. Similarly, research in the United States has revealed a low level of public confidence with only 29 percent of respondents expressing a high level of confidence in their criminal justice system (Sourcebook of Criminal Justice Statistics, 20I2). Studies conducted in Canada and the United Kingdom have also highlighted concerns regarding public confidence in the criminal justice system, with only around half of citizens ( $57 \%$ and $49 \%$, respectively) reporting a favorable level of confidence (Chaplin, Flatley, \& Smith, 20II; Statistics Canada, 2003).

Although there appears to be a lack of public confidence in the criminal justice system as a whole in some Western nations, it is important to differentiate between the institutions that form the criminal justice system, as research shows that the public perceives the courts very differently from how they perceive the police and prisons (Roberts, 2007). This difference is known as the "evaporation effect"- the distinct decrease in confidence moving from police through courts and to prisons (Indermaur \& Roberts, 2009). Results of a 2003 survey conducted in Australia revealed that a large majority of respondents (72\%) expressed "a great deal" or "quite a lot" of confidence in the police, whilst only 29 percent of respondents expressed the same amount of confidence in the courts and legal system (Bean, 2005). This evaporation effect has also 
been witnessed in Canada (Ipsos-Reid, 2002) and the United Kingdom (Hough \& Roberts, 2004).

It is plausible that the lack of public confidence specifically in the courts could be a result of the public's attitudes toward the sentencing of offenders. In a study assessing respondents' attitudes toward (and confidence in) the criminal courts, sentencing, and punishments, results revealed that public confidence in the sentencing of offenders was low, with the majority of confidence ratings in this area being negative (Mackenzie et al., 20I2). In particular, participants expressed doubts as to the appropriateness of sentencing decisions made by the courts. Despite the fact that the majority of respondents agreed that Judges should consider (and sentences should reflect) public opinion, participants were not confident that "Judges are in touch with what ordinary people think" (p. 49). In addition, the majority of respondents believed that sentences given to offenders are too lenient, particularly for violent crimes. It therefore seems unsurprising that the majority of participants believe that offenders should be given more severe sentences for their crimes. This desire for harsher sentences is also evident in other countries (Enns, 20I4; Hough, Bradford, Jackson, \& Roberts, 20I3) and indicates that citizens who believe that offenders should be given stiffer sentences generally have lower confidence in courts (Roberts \& Indermaur, 2009).

Indermaur and Roberts (2009) strongly argue that the best way to improve public confidence in sentencing and reflect public opinion in sentencing decisions is to strengthen the perception that the courts are acting on behalf of the public. Gleeson (2004) proposes that the most sensible way for the courts to act on behalf of the citizens is through the jury system. Many researchers agree, suggesting that involving the public in criminal justice system processes may be the best way to increase public confidence (Green, 2006; Indermaur, 2008; Maruna \& King, 2004).

\section{B. Jury Sentencing Recommendations}

One way to involve citizens in the criminal justice system is to allow jurors, as members of the public, to be involved in sentencing decisions (Iontcheva, 2003). Current sentencing practice in many adversarial judicial systems, including Australia where the present research was conducted, does not allow for jury involvement in the sentencing process (Judicial Conference of Australia, 2007). However, one Australian state government recently proposed 
a reform to introduce jury sentencing recommendations as a means to increase public confidence in the courts (Andrews \& Pakula, 20I3). The reform proposed that, following a guilty verdict, the jury would deliberate on an appropriate minimum time that an offender should be incarcerated (i.e., minimum non-parole period). The Judge would then receive and review the jury's recommendation and-although not required to agree with or hand down the jury's recommendation-would be required to reveal it at the sentencing hearing, along with any reasons for disagreement, if applicable. Despite the intention of the reform to increase public confidence, the effectiveness of jury sentencing recommendations for this purpose is unclear. Although the implementation of jury sentencing recommendations would be a first in Australia, jury involvement in sentencing is by no means a new concept. In France and Japan, mixed-court system comprised of Judges and jurors rule on the question of guilt and set sentences together (Anderson \& Saint, 2005; McKee, 200I). However, France and Japan both operate under an inquisitorial justice system, which is a vastly different model of justice than the adversarial system on which the current research is based (Shchepetova, 2013). Thus for the purposes of this article, we will focus on jury sentencing recommendations in adversarial systems.

One adversarial system that involves juries in sentencing decisions is Canada. Section 745.2 of the Criminal Code of Canada (1985) states that a jury has the opportunity to recommend a minimum non-parole period to the presiding Judge, but only in cases where the accused has been found guilty of second degree murder. A person found guilty of second degree murder in Canada must be sentenced to life imprisonment with a minimum non-parole period of Io years; however, the jury may recommend that the offender serve anywhere between Io and 25 years non-parole (Vidmar, 1999). It must be noted that the involvement of the jury in making this recommendation is an option, not a requirement (Granger, 1996).

In the United States, juries have played a role in the sentencing for more than 200 years (Iontcheva, 2003). Jury involvement in sentencing was originally implemented because of citizen concerns that Judges were not representative and that a jury would be better suited to the task as they are more familiar with the circumstances and background of defendants and their offenses (Hoffman, 2003). Today, six states in America still employ jury sentencing; however, variations exist in how it is practiced (King \& Noble, 2004). In all six states, the same jury that delivers a guilty verdict 
goes on to determine an appropriate sentence for the offender after reviewing any aggravating or mitigating factors put forward by the prosecution or defense (Mann \& Blunden, 20Io). A unanimous verdict regarding the sentence is required, but if the jury cannot reach a unanimous verdict, the sentencing decision is passed on to the Judge (Horne, 1996). In most states, Judges have the authority to impose a more lenient sentence if they feel that the jury's sentence was unfairly punitive; however, none of the states practicing jury sentencing allow Judges to impose a more punitive sentence than the jury (Iontcheva, 2003).

Despite the use of jury sentencing in the United States, there is mixed support for it. On one hand, researchers argue that juries impose sentences that are more variable (Weninger, 1994; Wright, 1999) and systematically harsher (Ostrom, Kauder, \& Kuban, 1996) than sentences imposed by Judges because of their lack of knowledge and experience of the criminal justice system. However, empirical research on jury sentencing is scarce, and in instances where it does exist, mixed results have been found (Smith \& Stevens, 1984; St Amand \& Zamble, 200I; Sunstein, 2002; Webster, 1960). On the other hand, prosecutors (King \& Noble, 2004) and victim support groups (NSWLRC, 2006) are supportive of jury sentencing recommendations as a means of communication and collaboration between the public and the criminal justice system. There is also public support for jury recommendations, as the public perceives jurors to be markedly fairer decision makers in criminal trials than Judges (MacCoun \& Tyler, 1988).

\section{Procedural Justice and Legitimacy}

Procedural justice (or procedural fairness) refers to the notion that individuals not only pay attention to the outcomes of decision-making processesan instrumental approach known as distributive justice-but also place importance on the procedures used to arrive at these decisions (Thibaut $\&$ Walker, 1975). As such, procedural justice is often referred to as a processbased model of regulation (Tyler \& Huo, 2002). Four key components are suggested to comprise this process-based model: trustworthiness, respect, neutrality, and voice (Goodman-Delahunty, 20Io). "Trustworthiness" refers to the degree to which people perceive that authorities are honest and concerned about the best interests of the community (Tyler \& Huo, 2002); "respect" refers to the extent to which people perceive that authorities take them seriously and display professional conduct (Goodman-Delahunty, 
20I0). "Neutrality" is the extent to which procedures and decisions are transparent, fair, and without bias (Tyler, 2007); "voice" refers to the opportunity for citizens to express their views and opinions about decisions (Hirschman, 1970). This process-based model suggests that subjective judgments regarding the fairness of procedures can powerfully influence one's attitudes toward the institutions that enact such procedures (Gonzalez \& Tyler, 2007; Tyler, 1990, 2003; Tyler \& Huo, 2002).

When institutions operate in accordance with procedures that are seen as fair, they will gain loyalty, trust, and confidence from participants (Cohen, 1985; Goodman-Delahunty, 20I0). Tyler (200I) investigated the factors that contribute to public trust and confidence in police and the courts. The study contrasted participants' judgments about distributive elements, such as performance (e.g., whether crime is controlled effectively), with judgments about fairness (e.g., how fairly citizens are treated) to determine their importance as precursors to confidence. The results suggested that judgments about both performance and effectiveness were considered when making evaluations about public confidence in police and the courts. However, fairness judgments were the most consistent and important factor influencing participants' confidence. Similarly, Rottman (2005) found that perceptions of fairness of the courts were the strongest predictor of public trust and confidence.

Perceptions of procedural justice are also associated with legitimacythe belief that authorities are entitled to be obeyed (Bradford, 2oII; Hough, Jackson, Bradford, Myhill, \& Quinton, 20IO). Legitimacy is necessary for authorities to ensure effective performance, cooperation, and maintenance of order (Beetham, 199I). The loss of legitimacy can result in detrimental consequences, particularly within the criminal justice system. If citizens do not view police or the courts as legitimate, they are unlikely to comply or cooperate with these authorities (Moore, 1997). To illustrate this, Sunshine and Tyler (2003) examined the relationship between citizen's perceived legitimacy of the New York City Police Department and their compliance with the law. Results revealed that higher perceptions of police legitimacy significantly predicted citizens' compliance with police.

Although some research suggests that instrumental elements of distributive fairness can be important for public judgements of legitimacy (e.g., Murphy \& Cherney, 20II), Tyler (1990) argues that procedural justice is the key antecedent to legitimacy. If the procedures that an institution enacts are seen as fair, then the institution itself will be seen as more legitimate (Gibson, 
1989; Tyler, 2003). For example, Mazerolle and colleagues (2012) found that a more procedurally fair encounter with police led to higher levels of confidence and trust in police, as well as higher perceptions of police fairness and legitimacy. Over time, these gains in public confidence and perceptions of legitimacy, as a result of procedural justice, can contribute to the overall strength of an institution (Cohen, 1985).

\section{Voice}

Voice is considered to be one of the most influential elements of procedural justice (Hirschman, 1970, 1974), as it provides individuals with the opportunity to express their thoughts and opinions about decisions before they are made (Tyler, 2007). When people have this opportunity, satisfaction with outcomes and perceptions of fairness are markedly higher compared to when individuals cannot voice their thoughts and opinions (Folger, 1977). This positive effect of voice is considered to be one of the most consistent findings in procedural justice research (Tyler $\&$ Lind, 1988) as it has been demonstrated in a variety of settings including legal dispute resolution (LaTour, 1978; Lind, Kurtz, Musante, Walker, \& Thibaut, 1980), organizational settings (Earley \& Lind, 1987), politics (Tyler, Rasinski, \& Spodick, 1985), and family conflict (Fondacaro et al., 2006).

For example, Tyler and colleagues (1985) examined the effect of voice on perceived fairness and satisfaction with a city council. Undergraduate university participants read a short scenario regarding the city council's allocation of tax money. Voice was manipulated by saying either that citizens were allowed to listen to the council debate but not participate (voice absent) or that citizens were able to speak to the council (voice present). Participants then made a series of judgments about the scenario. Participants who read that citizens had a voice in the council's decision were more likely to rate the process and decision as fair and evaluated the council more positively than participants who read that citizens did not have a voice in the decision-making process.

\section{E. The "Frustration Effect"}

Despite the positive effects of voice on perceptions of procedural fairness and satisfaction with outcomes, simply having voice is sometimes not enough (Ulbig, 2008). Under certain circumstances, the inclusion of voice in decision-making processes may decrease perceptions of procedural 
fairness and satisfaction with outcomes (Goodwin \& Ross, 1992; Potter, 2006). Cohen (1985) suggests that this negative effect of voice on fairness judgments, known as the "frustration effect," occurs when participants believe their participation and voice in the decision-making process was used only to persuade them to accept the outcome (i.e., when voice is not given with trustworthy motives). For instance, decision makers may invite participants to voice their thoughts and opinions, yet proceed to ignore these opinions in a self-interested manner (Tyler et al., 1985). This leads participants to believe that their voice in the decision-making process was not adequately considered - and was given as a token gesture, rather than a true effort to engage with participants-and therefore had minimal influence on the outcome (Avery \& Quiñones, 2002; Tyler \& Lind, 1988). Such instances may lead the participant to suspect that the process was unfair (Lind \& Lissak, 1985), thus voice would lead to a negative effect on perceptions of fairness rather than the intended positive effect (Folger, 1977; Goodwin \& Ross, 1992). Tyler and McGraw (1986) suggest that, for voice to have a positive effect on the perceived fairness of procedures, it is essential for participants to believe that their voice has been given adequate consideration and has had an influence on the decision-making process. Therefore, a voice perceived to have little or no influence may be more harmful than not having a voice at all (Avery \& Quińones, 2002; Ulbig, 2008).

\section{THE CURRENT RESEARCH}

Through two studies, the current research aims to evaluate empirically the effectiveness of jury sentencing recommendations using elements of procedural justice theory. Jury sentencing recommendations would allow the jury, as representatives of the public, to have a voice in the decisionmaking process. As such, the first study aimed to investigate whether jury sentencing recommendations, which allow voice, would lead to greater public confidence and perceptions of fairness and legitimacy. However, as Judges may not necessarily be required to adopt the jury's recommendation, the second study aimed to examine whether a Judge's disagreement with a jury's recommendation would elicit the "frustration effect" and thus lead to lower public confidence and perceptions of fairness and legitimacy. 


\section{STUDY 1}

Study I was designed to examine whether the use of jury sentencing recommendations can increase public confidence and perceptions of procedural fairness and legitimacy in the criminal courts. Using hypothetical news reports of a murder crime and sentencing hearing, the study manipulated presence of voice (voice present, voice absent) and punitiveness (more punitive, less punitive) to examine three predictions. Firstly, we predicted that when voice was present, confidence and perceptions of fairness and legitimacy of the particular case would be higher than when voice was absent $(\mathrm{HI})$. Secondly, we predicted that this effect would also occur for confidence and perceptions of fairness and legitimacy of the criminal courts in general $\left(\mathrm{H}_{2}\right)$. Thirdly, as public confidence appears to be driven by the perception that Judges impose sentences that are too lenient, we predicted that voice would only have an effect when a more lenient sentence was given. More specifically, when the minimum nonparole period was less punitive, confidence and perceptions of fairness and legitimacy were predicted to be higher when voice was present compared than when voice was absent $\left(\mathrm{H}_{3} \mathrm{a}\right)$. However, when the minimum nonparole period was more punitive, confidence and perceptions of fairness and legitimacy were predicted to have no difference depending on whether voice was present or absent $\left(\mathrm{H}_{3} b\right)$.

\section{A. Method}

\section{Participants and design}

Eighty undergraduate psychology students at a large Australian university (48 female, 32 male: $M_{\text {age }}=18.68, S D=3.00$ ) participated in the study for course credit. Participants were randomly assigned to one of four conditions formed by the between-groups manipulation of presence of voice (voice absent, voice present) and punitiveness (more punitive, less punitive). Random assignment resulted in 19 participants in the "voice absent, more punitive" condition, 2I participants in the "voice present, more punitive" condition, and 20 participants in each of the remaining two conditions. ${ }^{1}$

I. A power analysis revealed that this sample size provided power of .845 to detect an effect of $f=.400$ or above (large effect), and power of .578 to detect an effect of $f=.300$ or above (medium effect). 


\section{Procedure and materials}

Participants were presented with one of four different versions of a hypothetical news report based on a real murder crime (Boddy, 2013). Participants read that the offender broke into the victim's house in the middle of the night to steal money. When the victim woke and threatened to call the police, the offender "panicked" and hit the victim twice over the head with an axe, covered the victim's body in carpets, and stole jewelry before fleeing the house.

a. Manipulation of presence of voice. In the voice absent condition, the Judge sentenced the offender to a period of incarceration with a minimum non-parole period. This reflects current sentencing practice in Australia, where the presiding Judge determines a defendant's sentence and minimum non-parole period (Judicial Conference of Australia, 2007). In the voice present condition, participants read that new sentencing reforms now require juries to recommend a minimum non-parole period to the Judge. As such, the jury made a minimum non-parole period recommendation to the Judge, and the Judge then sentenced the offender to a period of incarceration with the same minimum non-parole period that the jury recommended.

b. Manipulation of punitiveness. In the more punitive condition, the offender received a 20-year minimum non-parole period for his offense. Twenty years was chosen as this was the minimum non-parole period given to the real offender on which these hypothetical news reports were based on (Boddy, 2013). Additionally, 20 years is the minimum non-parole period that is generally given for a murder offense in the study jurisdiction (Sentencing Advisory Council, 20II). In the less punitive condition, the offender received a I5-year minimum non-parole period for his offense. Fifteen years was chosen as it is the shortest minimum non-parole period that can be set for a murder offense in the study jurisdiction (Department of Justice and Attorney-General, 20I2).

c. Measures. After reading the news report, participants completed a short questionnaire exploring a variety of constructs related to the specific case and perceptions of the courts more generally. The constructs included confidence in sentencing for the particular case (6 items, adapted from 
Mackenzie et al., 20I2), perceptions of procedural fairness (one item) and legitimacy (one item) of the particular case, perceived influence of the jury in the sentencing decision (one item), confidence in sentencing for the criminal courts in general ( 7 items, adapted from Mackenzie et al., 20I2), perceptions of procedural fairness of the criminal courts in general ( 7 items, adapted from Gibson, Caldeira, \& Spence, 2003). All of these measures used a 5-point Likert scale and were found to be reliable $(\alpha=.74$ to .85 ; see Appendix B for items used in each construct).

To assess the manipulation of voice, participants were asked whether or not the jury recommended a minimum non-parole period to the Judge. If participants responded "yes," they were then asked to select the length of the minimum non-parole period that the jury recommended from four available options ( 5 , IO, I5, or 20 years). Further, participants were asked to indicate how much influence the jury had on the sentencing decision (5-point Likert scale). To assess the manipulation of punitiveness, participants were asked to select the length of the minimum non-parole period that the defendant received from four available options (5, IO, I5, or 20 years).

\section{B. Results}

The majority of participants correctly identified the length of the jury's sentencing recommendation $(96 \%)$ and the length of the sentence given to the offender (99\%). The presence of voice manipulation also had a significant impact on participants' perceptions of the jury's influence in the sentencing decision. Participants who read that the jury did have a voice in sentencing the offender felt the jury had a greater influence in deciding the defendant's sentence $(M=3.88, S D=0.92)$ than participants who read that the jury did not have a voice in $(M=3.00, S D=\mathrm{I} .32), t(78)=3.46$, $p=$.ooI, $d=.77$.

\section{Bivariate correlations}

Pearson correlation coefficients (see Table I) showed that voice was positively correlated with perceived influence of the jury in the sentencing decision $(r=.37, p<$.oor). Furthermore, perceived procedural fairness of the particular case was positively correlated with confidence in sentencing $(r=.37, p=$. ooI $)$ and perceived legitimacy $(r=.44, p<$. ooI $)$ of the particular case. Additionally, perceived procedural fairness of the courts in 
Table 1. Bivariate correlations between Study 1 variables.

\begin{tabular}{|c|c|c|c|c|c|c|c|c|c|}
\hline & 1 & 2 & 3 & 4 & 5 & 6 & 7 & 8 & 9 \\
\hline 1. Voice (IV) & - & .03 & $.37^{\star \star \star}$ & -.11 & -.01 & .07 & .02 & -.11 & -.15 \\
\hline 2. Punitiveness (IV) & & - & .08 & .09 & .13 & $.23^{\star}$ & -.15 & .04 & -.07 \\
\hline 3. Influence & & & - & -.08 & .07 & .12 & -.02 & -.06 & -.19 \\
\hline $\begin{array}{l}\text { 4. Confidence in } \\
\text { sentencing (case) }\end{array}$ & & & & - & $.37^{\star \star}$ & $.44^{\star \star \star}$ & $.23^{*}$ & $.23^{*}$ & .02 \\
\hline $\begin{array}{l}\text { 5. Procedural fairness } \\
\text { (case) }\end{array}$ & & & & & - & $.52^{\star \star \star}$ & .16 & .19 & -.12 \\
\hline 6. Legitimacy (case) & & & & & & - & .07 & .11 & -.10 \\
\hline $\begin{array}{l}\text { 7. Confidence in } \\
\text { sentencing (general) }\end{array}$ & & & & & & & - & $.54^{\star \star \star}$ & $.32^{\star \star}$ \\
\hline $\begin{array}{l}\text { 8. Procedural fairness } \\
\text { (general) }\end{array}$ & & & & & & & & - & $.29^{\star}$ \\
\hline 9. Legitimacy (general) & & & & & & & & & - \\
\hline
\end{tabular}

Note. All variables are scaled so that higher values indicate a higher degree. IV $=$ independent variable.

${ }^{\star} p<.05,{ }^{* *} p<.01,{ }^{\star \star *} p<.001$.

general was positively correlated with confidence in sentencing $(r=.54$, $p<$. .ooI $)$ and perceived legitimacy $(r=.29, p=$. oro $)$ of the courts in general. Confidence in sentencing for the particular case was positively associated with confidence in sentencing for the courts in general $(r=$ $.23, p=.043)$. However, perceived procedural fairness of the particular case was not associated with perceived procedural fairness of the courts in general $(r=.19, p=.096)$, and perceived legitimacy of the particular case was not associated with perceived legitimacy of the courts in general $(r=$ -$. IO, $p=.395)$.

2. Confidence in sentencing, procedural fairness, and legitimacy (case)

A series of 2 (presence of voice) x 2 (punitiveness) between-groups factorial ANOVAs were conducted to assess whether participants' confidence in sentencing, perceptions of fairness, or perceptions of legitimacy for this particular case were affected by presence of voice (HI), and if this effect was moderated by punitiveness $\left(\mathrm{H}_{3}\right)$. Contrary to predictions, there was no significant main effect of presence of voice, all $F_{\mathrm{S}}(\mathrm{I}, 76)<0.99, p s>.323$, 
$\eta_{\mathrm{p}}{ }^{2} \mathrm{~s}<$.oI, and no significant interaction between presence of voice and punitiveness, all $F_{\mathrm{S}}(\mathrm{I}, 63)<\mathrm{I} . \mathrm{I} 8, p \mathrm{~s}>.28 \mathrm{I}, \eta_{\mathrm{p}}{ }^{2} \mathrm{~s}<.02$.

However, a significant main effect of punitiveness emerged when legitimacy was the outcome of interest, $F(\mathrm{I}, 76)=4.3 \mathrm{I}, p=.04 \mathrm{I}, \eta_{\mathrm{p}}{ }^{2}=.05$, such that the process used to determine the defendant's minimum nonparole period was perceived to be more legitimate when the defendant's minimum non-parole period was more punitive $(M=3.75, S D=0.67)$ compared to when the defendant's minimum non-parole period was less punitive $(M=3.43, S D=0.7 \mathrm{I})$.

\section{Confidence in sentencing, procedural fairness, and legitimacy (general)}

A series of 2 (presence of voice) $\mathrm{x} 2$ (punitiveness) between-groups factorial ANOVAs were conducted to assess whether confidence in sentencing, perceptions of fairness, or perceptions of legitimacy of the criminal courts in general were affected by presence of voice $\left(\mathrm{H}_{2}\right)$, and if this effect was moderated by punitiveness $\left(\mathrm{H}_{3}\right)$. Contrary to hypothesis $\mathrm{H}_{2}$, there was no main effect of presence of voice for any of the outcomes, all $F_{\mathrm{S}}(\mathrm{I}, 76)<\mathrm{I} .8 \mathrm{I}$, $p s>.182, \eta_{\mathrm{p}}{ }^{2}<<.03$. However, there was a significant interaction between presence of voice and punitiveness on confidence in sentencing in general, $F(\mathrm{I}, 76)=4.28, p=.042, \eta_{\mathrm{p}}{ }^{2}=.05$, though procedural fairness and legitimacy were non-significant, $F_{s}(\mathrm{I}, 76)<2.55$, $p s>. \mathrm{II} 5, \eta_{\mathrm{p}}{ }^{2}<<.03$.

Simple effects analyses of voice within each level of punitiveness, using a Bonferroni correction to adjust for the family-wise error rate, were used to follow up the significant interaction for confidence in sentencing in general. As shown in Figure I and contrary to hypotheses $\mathrm{H}_{3} \mathrm{a}$ and $\mathrm{H}_{3}$ b, voice did not moderate the effect of punitiveness. When a less punitive minimum non-parole period was given, participants' confidence in sentencing for the criminal courts in general was the same regardless of whether voice was present or not, $F(\mathrm{I}, 76)=2.55, p=. \mathrm{II}_{4}, \eta_{\mathrm{p}}{ }^{2}=.03$. Likewise, when a more punitive minimum non-parole period was given, participants' confidence in sentencing for the criminal courts in general was the same regardless of whether voice was present or not, $F(\mathrm{I}, 76)=\mathrm{I} .76, p=. \mathrm{I} 88$, $\eta_{\mathrm{p}}^{2}=.02$.

\section{Legitimacy, confidence, and punitiveness (case): Mediation analyses}

To examine the main effect of punitiveness on perceived legitimacy of the particular case, a mediation analysis using bootstrapping was conducted 
Figure 1. Confidence in sentencing (general) as a function of presence of voice and punitiveness. Error bars represent standard error of the mean.

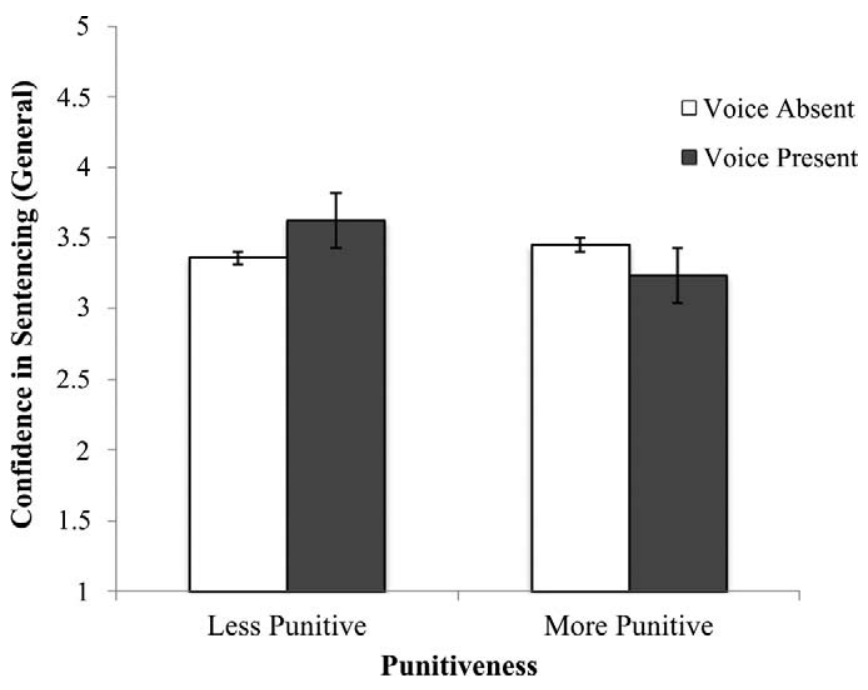

and reported as per Hayes (2013). The literature suggests that perceptions of legitimacy are positively associated with confidence (Mazerolle et al., 2013; Mazerolle et al., 20I2; Sunshine \& Tyler, 2003), and this notion was supported by our finding of a significant positive correlation between perceptions of legitimacy and confidence in sentencing of the particular case (see Table I). As such, it is plausible that punitiveness may indirectly affect confidence in sentencing for this particular case through the perceived legitimacy of the particular case. Additionally, confidence in sentencing for this particular case was positively correlated with confidence in sentencing for the criminal courts in general. As such, punitiveness may affect confidence in sentencing for the courts in general indirectly through perceived legitimacy and confidence in sentencing of the particular case.

Testing these plausible explanations, a mediation analysis conducted using ordinary least squares path analysis showed that punitiveness indirectly influenced confidence in sentencing of the criminal courts in general through its effect on perceived legitimacy and confidence in sentencing of the particular case (see Figure 2 for the mediation model). Participants who read that the offender received a more punitive minimum 
Figure 2. Mediation model for the relationship between punitiveness and confidence in sentencing (general) through legitimacy (case) and confidence in sentencing (case).

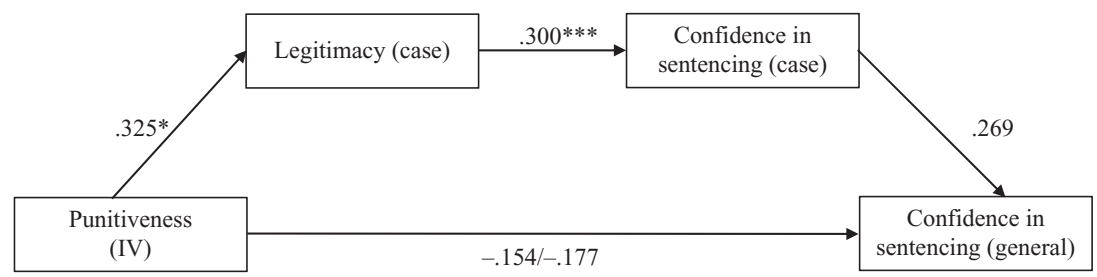

Note. All coefficients represent unstandardized coefficients. ${ }^{*} p<.05,{ }^{* \star *} p<.001$.

non-parole period were more likely to think the process used to determine the offender's minimum non-parole period was legitimate $(a=.325, p=$ .039). Furthermore, participants who had higher perceptions of legitimacy of the particular case were more likely to have higher confidence in sentencing for the particular case $(d=.300, p<.001)$. Finally, participants who had higher confidence in sentencing for the particular case also appeared to have higher confidence in sentencing for the criminal courts in general, however this effect did not reach significance $(b=.269, p=.053)$. A bias-corrected 95 percent confidence interval for the indirect effect $(a d b=.026)$ based on 5,00o bootstrap samples was entirely above zero (.003I to .0858), indicating that punitiveness influenced confidence in sentencing for the criminal courts in general through the perceived legitimacy and confidence in sentencing of the particular case. There was no evidence that punitiveness influenced confidence in sentencing of the courts in general, independent of its effect on the perceived legitimacy and confidence in sentencing of the particular case $\left(c^{\prime}=-.177, p=. \mathrm{I} 44\right)$.

\section{Preliminary Discussion}

Study I aimed to investigate whether jury sentencing recommendations, which allow voice, would increase public confidence and perceptions of fairness and legitimacy compared to sentencing practice that does not allow for voice. Although the presence of voice did impact participants' perceptions of the influence of the jury's influence in sentencing decisions, results of this study showed limited support for our predictions. Firstly, presence 
of voice was not found to have an impact on participants' confidence and perceptions of fairness or legitimacy (of the particular case, as well as the courts in general). Secondly, the effect of voice was not found to differ depending on the punitiveness of the minimum non-parole period, as there were no interactions between voice and punitiveness on perceptions of fairness or legitimacy, nor confidence in sentencing for the particular case. However, a significant disordinal interaction emerged for confidence in sentencing for the criminal courts in general. Further inspection of the interaction revealed that the simple effects of voice within each level of punitiveness were not significant. Thus, participants' confidence in sentencing for the criminal courts in general did not appear to vary as a function of whether voice was present or absent, or whether the offender received a less punitive or more punitive minimum non-parole period. Overall, the results of Study I suggest that, compared to current sentencing practice, introducing jury sentencing recommendations may not improve public confidence as intended (Andrews \& Pakula, 2013; Spigelman, 2005). However, this conclusion must be taken with caution, as alternative explanations regarding sample size and power will be considered in the general discussion.

Despite finding no support for our original hypotheses, an unexpected effect of punitiveness emerged. Results demonstrated that perceptions of legitimacy for the particular case were higher for participants who read that the offender received a more punitive minimum nonparole period compared to participants who read that the offender received a less punitive minimum non-parole period. Furthermore, through a mediation analysis using legitimacy and confidence in sentencing of the particular case as serial mediators, punitiveness was shown to have an indirect effect on general confidence in sentencing: participants' had higher confidence in the criminal courts when a more punitive sentence was given. Theoretically, this may indicate that distributive justice (Adams, 1973; Homans, 196I), which refers to the outcomes of decision making rather than the processes used, was more important for our participants. As such, the results may appear to support the notion, often referred to by politicians as being "tougher on crime" (Hora, 2013; Lethbridge, 20I3), that increasing sentences may increase public confidence and satisfaction with the criminal courts. However, the small effect size $\left(\eta_{\mathrm{p}}^{2}=.05\right)$ must be taken into consideration when making such inferences. 


\section{STUDY 2}

Although neither public confidence nor perceptions of fairness and legitimacy was increased by the jury's voice through jury sentencing recommendations presented in Study I, it is not unfathomable that a frustration effect (Avery \& Quiñones, 2002; Folger, 1977; Goodwin \& Ross, 1992; Ulbig, 2008) could occur when the jury is involved in sentencing decisions. A proposed jury sentencing recommendations reform in the Australian state of Victoria indicates that Judges would not be required to agree with, or hand down, the jury's recommendation and that the Judge must provide a reason for disagreement at the sentencing hearing (Andrews \& Pakula, 20I3). Therefore, disagreement could lead the public to believe that their voice, delivered through the jury, is not adequately considered. This may be further exacerbated if the Judge's reason for disagreement is considered to be unfair. As such, Judge disagreement with jury recommendation may elicit a "frustration effect," leading to a negative effect on public confidence and perceptions of fairness and legitimacy.

This study used similar hypothetical news reports as in Study I, however, jury sentencing recommendations (i.e., voice) were present in all conditions. The current study manipulated the Judge's agreement with the jury's recommendation, as well as the jury's perceptions of the fairness of the Judge's reason for disagreement to form three experimental conditions: Judge agree, Judge disagree—fair, Judge disagree—unfair. Firstly, we predicted that when the Judge disagreed with the jury's recommendation, confidence and perceptions of fairness and legitimacy of the particular case would be lower compared to when the Judge agreed with the jury's recommendation $(\mathrm{HI})$. Secondly, we predicted that this effect would also occur for confidence and perceptions of fairness and legitimacy of the criminal courts in general, such that when the Judge disagreed with the jury's recommendation, confidence and perceptions of fairness and legitimacy of the criminal courts would be lower compared to when the Judge agreed with the jury's recommendation $\left(\mathrm{H}_{2}\right)$. Thirdly, we predicted that when the Judge disagreed with the jury's recommendation, confidence and perceptions of fairness and legitimacy of the particular case would be higher when the Judge's reason for disagreement was perceived to be fair compared to when the reason was perceived to be unfair $\left(\mathrm{H}_{3}\right)$. Finally, we predicted that this effect would also occur for confidence and perceptions of fairness and legitimacy of the criminal courts in general, such that 
confidence and perceptions of fairness and legitimacy of the criminal courts in general would be higher when the Judge's reason for disagreement was perceived to be fair compared to unfair $\left(\mathrm{H}_{4}\right)$.

\section{A. Method}

\section{Participants and design}

Sixty undergraduate psychology students at a large Australian university (42 female, I8 male: $M_{\text {age }}=2 \mathrm{I} .3 \mathrm{I}$ years, $S D=7.25$ ) participated in the study for course credit. Participants were randomly assigned to one of three conditions formed by the between-groups manipulation of Judge's agreement with the jury's recommendation (Judge agree, Judge disagree-fair, Judge disagree-unfair). ${ }^{2}$

\section{Procedure and materials}

Participants were presented with one of three different versions of a hypothetical news report, based on the same murder crime as in Study I. Participants received the same information about the crime as in Study I; however, unlike Study I, voice was present in all three conditions. Thus, all participants were given brief information regarding jury sentencing recommendations and read that the jury made a recommendation of a 20-year minimum non-parole period to the Judge (see Appendix B for items).

a. Manipulation of Judge agreement with jury's recommendation. In the "Judge agree" condition, the Judge agreed with the jury's recommendation and sentenced the offender to a period of incarceration with a minimum non-parole period of 20 years. In the "Judge disagree—fair" condition, the Judge disagreed with the jury's recommendation and sentenced the offender to a period of incarceration with a minimum non-parole period of 15 years. The Judge's reason for disagreement was also provided, and the jury indicated that they thought this reason was fair. In the "Judge disagree- unfair" condition, the Judge disagreed with the jury's recommendation and

2. A power analysis revealed that this sample size provided power of .776 to detect an effect of $f=.400$ or above (large effect), and power of .5I4 to detect an effect of $f=.300$ or above (medium effect). 
sentenced the offender to a period of incarceration with a minimum nonparole period of is years. The Judge's reason for disagreement was also provided, and the jury indicated that they thought this reason was unfair.

b. Measures. The same measures were used as in Study I. To check the manipulation of the Judge's agreement with the jury's recommendation, participants were asked whether the Judge agreed or disagreed with the jury's recommendation. If participants responded "disagree," they were then asked whether the jury indicated that the Judge's reason was fair or unfair. All participants were asked to select the length of the minimum non-parole period that the defendant received from four available options (5, IO, I5, or 20 years).

\section{B. Results}

The majority of participants (97\%) correctly identified the sentence length that the offender received. Participants were more likely to report that the jury was influential in deciding the defendant's minimum non-parole period when they read that the Judge agreed with the jury's recommendation $(M=3.55, S D=0.69)$, than if they read that the Judge had disagreed with the jury's recommendation, regardless of whether the Judge provided a fair reason $(M=2.50, S D=0.89)$ or unfair reason $(M=2.70, S D=$ o.75), $F(2,57)=$ I3.68, $p=<.001, \eta^{2}=.32$.

\section{Bivariate correlations}

Pearson correlation coefficients (see Table 2) showed that the Judge's agreement with the jury's sentencing recommendation was negatively correlated with perceived influence of the jury in the sentencing decision $(r=$ $-.53, p<.00 I)$, such that the jury was less likely to be perceived as being influential when the Judge disagreed with the jury's recommendation. Influence was also found to be positively correlated with perceptions of fairness $(r=.302, p=.019)$ and legitimacy $(r=.32, p=.013)$ of the case, such that the more influential the jury was perceived to be, the more participants saw the procedure used to determine the defendant's sentence to be fair and legitimate. (However, the relationship between influence and fairness/legitimacy was not significant for more general perceptions about the courts, $p$ s $>.05$.) 
Table 2. Bivariate correlations between Study 2 variables.

\begin{tabular}{|c|c|c|c|c|c|c|c|c|}
\hline & 1 & 2 & 3 & 4 & 5 & 6 & 7 & 8 \\
\hline 1. Judge's agreement (IV) ${ }^{a}$ & - & $-.53^{\star \star \star}$ & -.21 & $-.28^{\star}$ & -.17 & .06 & .17 & .02 \\
\hline 2. Influence & & - & .24 & $.30^{*}$ & $.32^{\star}$ & .10 & -.03 & -.17 \\
\hline $\begin{array}{l}\text { 3. Confidence in } \\
\text { sentencing (case) }\end{array}$ & & & - & $.55^{\star \star \star}$ & $.49^{\star * \star}$ & $.59^{\star \star \star}$ & .19 & -.16 \\
\hline $\begin{array}{l}\text { 4. Procedural fairness } \\
\text { (case) }\end{array}$ & & & & - & $.70^{\star \star \star}$ & $.45^{\star \star \star}$ & .24 & -.08 \\
\hline 5. Legitimacy (case) & & & & & - & $.39^{\star \star}$ & .20 & -.18 \\
\hline $\begin{array}{l}\text { 6. Confidence in } \\
\text { sentencing (general) }\end{array}$ & & & & & & - & $.57^{\star \star \star}$ & -.24 \\
\hline $\begin{array}{l}\text { 7. Procedural fairness } \\
\text { (general) }\end{array}$ & & & & & & & - & $-.31^{*}$ \\
\hline 8. Legitimacy (general) & & & & & & & & - \\
\hline
\end{tabular}

Note. All variables are scaled so that higher values indicate more of the variable.

a Coded so that 1 = Judge agree, 2 = Judge disagree (fair), and $3=$ Judge disagree (unfair).

${ }^{\star} p<.05,{ }^{* *} p<.01,{ }^{* \star *} p<.001$.

Furthermore, perceived procedural fairness of the particular case was positively correlated with confidence in sentencing $(r=.55, p<$. .oor $)$ and perceived legitimacy $(r=.70, p<$. oor $)$ of the particular case. Additionally, it was found that perceived procedural fairness of the criminal courts in general was positively correlated with confidence in sentencing $(r=.57, p<$ .OOI) and perceived legitimacy ( $r=.3 \mathrm{I}, p=.0 \mathrm{I} 7)$ of the criminal courts in general. Confidence in sentencing for the particular case was found to be positively associated with confidence in sentencing for the criminal courts in general $(r=.59, p<$.ooI). However, perceived procedural fairness of the particular case was not associated with perceived procedural fairness of the criminal courts in general $(r=.24, p=.064)$, and perceived legitimacy of the particular case was not associated with perceived legitimacy of the criminal courts in general $(r=-.18, p=.178)$.

2. Confidence in sentencing and perceptions of procedural fairness and legitimacy (case)

One-way between-groups ANOVAs were conducted to determine whether confidence in sentencing and perceptions of procedural justice and legitimacy 
Table 3. Cell means and standard deviations for each outcome measure (case) as a function of Judge's agreement with the jury's recommendation.

\begin{tabular}{lcccc}
\hline & Judge agree & $\begin{array}{c}\text { Judge } \\
\text { disagree } \\
\text { (fair) }\end{array}$ & $\begin{array}{c}\text { Judge } \\
\text { disagree } \\
\text { (unfair) }\end{array}$ & \multicolumn{1}{c}{ Totals } \\
\hline Confidence in sentencing (case) & $3.54(0.62)$ & $3.17(0.79)$ & $3.16(0.76)$ & $3.29(0.74)$ \\
Procedural fairness (case) & $3.70(0.73)$ & $3.60(1.05)$ & $3.05(1.00)$ & $3.45(0.96)$ \\
Legitimacy (case) & $3.70(0.73)$ & $3.50(1.00)$ & $3.30(1.08)$ & $3.50(0.95)$ \\
\hline
\end{tabular}

for the particular case were affected by the Judge's agreement with the jury's recommendation $(\mathrm{HI})$ and the Judge's reason for disagreement $\left(\mathrm{H}_{3}\right)$. Contrary to predictions, there were no significant effects of Judge's agreement with the jury's recommendation, or reason for disagreement, on any of these outcomes, $F_{s}(2,57)<2.80$, ps $>069, \eta^{2} s<.09$. (See Table 3 for means and standard deviations).

3. Confidence in sentencing and perceptions of procedural fairness and legitimacy (general)

One-way between-groups ANOVAs were conducted to determine whether confidence in sentencing and perceptions of procedural justice and legitimacy of the criminal courts in general were affected by the Judge's agreement with the jury's recommendation $\left(\mathrm{H}_{2}\right)$ and the Judge's reason for disagreement $\left(\mathrm{H}_{4}\right)$. Contrary to predictions, there were no significant effects of Judge's agreement with the jury's recommendation on any of the outcomes, $F_{\mathrm{S}}(2,57)<\mathrm{I}$.OI, $p$ s $>$.37I, $\eta^{2} \mathrm{~s}=$ all .03. (See Table 4 for means and standard deviations.)

\section{Preliminary Discussion}

Study 2 aimed to investigate whether a frustration effect would occur if a Judge disagreed with a jury's recommendation. Our results showed that participants viewed jurors as more influential when the Judge agreed with their recommendations than when the Judge disagreed, regardless of whether the reason for disagreement was seen as fair or not. Further, we found that participants who perceived the jury to be more influential were more likely to believe that the case was procedurally fair and legitimate, 
Table 4. Cell means and standard deviations for each outcome measure (general) as a function of Judge's agreement with the jury's recommendation.

\begin{tabular}{lccccc}
\hline & Judge agree & $\begin{array}{c}\text { Judge } \\
\text { disagree } \\
\text { (fair) }\end{array}$ & $\begin{array}{c}\text { Judge } \\
\text { disagree } \\
\text { (unfair) }\end{array}$ & \multicolumn{1}{c}{ Totals } \\
\hline Confidence in sentencing (general) & $3.37(0.41)$ & $3.24(0.74)$ & $3.45(0.45)$ & $3.35(0.55)$ \\
Procedural fairness (general) & $3.42(0.53)$ & $3.61(0.55)$ & $3.63(0.44)$ & $3.55(0.51)$ \\
Legitimacy (general) & $3.29(0.55)$ & $3.06(0.68)$ & $3.25(0.60)$ & $3.20(0.61)$ \\
\hline
\end{tabular}

though these findings did not extend to more general perceptions of the courts.

However, contrary to predictions, participants' confidence and perceptions of fairness and legitimacy (of the particular case, as well as the criminal courts in general) did not differ depending on whether the Judge agreed or disagreed with the jury's recommendation. Additionally, we did not find that confidence and perceptions of fairness and legitimacy were lower when the Judge disagreed with an unfair reason compared to a fair reason. Despite frustration effects previously found in the context of political decision making (Ulbig, 2008) and decision making in regard to the scheduling of a university orientation week (Avery \& Quiñones, 2002), our findings did not provide support for this effect. Thus, these findings indicate that public confidence may not differ depending on whether Judges agree or disagree with a jury's recommendation, or whether the reason for the Judge's disagreement is considered to be fair or unfair. However, this is noted with caution, as limitations of power may restrict the ability to make a firm conclusion.

A potential alternative explanation for the result also exists. In the condition where the Judge agreed with the jury's recommendation, the final minimum non-parole period given to the offender was 20 years. However, in the two conditions where the Judge disagreed with the jury's recommendation, the final minimum non-parole period given to the offender was is years. Therefore, the minimum non-parole period that the offender received systematically differed depending on whether the Judge agreed or disagreed with the jury's recommendation. This systematic difference was unavoidable, as it would not make sense for a jury to recommend a minimum non-parole period of 20 years and then for the Judge to disagree with this recommendation, but still hand down this minimum 
non-parole period of 20 years to the offender. Alternatively, we could have chosen to not inform participants of the jury's recommendation to the Judge. However, we wanted to ensure the study was as consistent as possible with the proposed jury sentencing recommendations reform in Australia, which state that if the Judge disagrees with the jury's recommendation, they would be required to reveal it at the sentencing hearing (Andrews \& Pakula, 2013).

\section{GENERAL DISCUSSION}

The aim of the current research was to empirically evaluate the effectiveness of jury sentencing recommendations using elements of procedural justice theory. Despite the longstanding use of jury sentencing recommendations in the United States (see Iontcheva, 2003) and the proposed implementation of jury sentencing recommendations in one Australian state (Andrews $\&$ Pakula, 20I3), prior to this study there was no known empirical evidence evaluating its influence on public confidence. The current research began to fill this gap in the literature with two studies. Firstly, it investigated whether jury sentencing recommendations - through the procedural justice element of voice-would lead to greater public confidence and perceptions of fairness and legitimacy compared to current sentencing practices in Australia that do not allow for voice. Although our results indicated that voice did impact how influential the jury was perceived to be, results revealed that confidence, fairness, and legitimacy did not differ as a result of whether voice was present or absent. Somewhat unexpectedly, we found that participants had higher confidence in the criminal courts in general when a more punitive sentence was given.

The second study investigated whether a frustration effect would occur if the Judge disagreed with the jury's recommendation, leading to a decrease in public confidence and perceptions of fairness and legitimacy. Again, although we found that our manipulation of Judge's agreement or disagreement with the jury's sentencing recommendation had an impact on how influential the jury were perceived to be, results did not reveal our hypothesized effects on public confidence, fairness, or legitimacy.

Despite a lack of support for the hypotheses, the current research provides an array of important practical and theoretical contributions to the literature. The current research provides a unique and important stepping 
stone for future research into jury sentencing recommendations, as well as the effects of procedural justice (particularly voice) on public confidence. Theoretically, the current research applied procedural justice theory to a novel context, jury sentencing recommendations. As voice was not found to have an effect on public confidence or perceptions of fairness or legitimacy, these findings suggest that jury sentencing recommendations may not be an effective means of increasing public confidence. Furthermore, the current research may indicate that other elements of procedural justice may be more influential and thus be required to have an effect on confidence and perceptions of fairness and legitimacy, as suggested by GoodmanDelahunty (20IO). Similarly, as the frustration effect was not replicated in the current research, this further suggests that jury sentencing recommendations may have no effect on confidence and perceptions of fairness and legitimacy, regardless of whether the Judge agrees or disagrees with the recommendation.

Practically, these findings strongly highlight the importance of empirically testing and evaluating reforms before they are implemented. For example, in many jurisdictions, jurors are provided with a daily remuneration (e.g., O’Brien, Goodman-Delahunty, Clough, \& Pratley, 2008). Therefore, if jury sentencing recommendations were implemented, more money would need to be spent for the increase in jury service time required. If the reform was ineffective at increasing public confidence, then this would result in a loss of economic resources as well as time. Thus, the importance of empirically evaluating reforms to see if they are effective before implementation can help to reduce these losses.

The present research offers a number of strengths and limitations. Firstly, the experimental design of both studies, including random assignment and standardized procedures, allowed us to investigate any causal inferences of the independent variables whilst ensuring that any potential confounds were minimized. Additionally, the current research ensured a high level of external validity by employing hypothetical news reports that were based on a real murder crime (Boddy, 2013) and ensuring that the studies were consistent with the jury sentencing recommendations reform proposed in one Australian state (Andrews \& Pakula, 2013).

One limitation of the current study is that pre-existing attitudes toward the courts were not taken into account in the current research. This was purposely done, as measuring these pre-existing attitudes prior to reading the news report may have primed the participants and led them to become 
aware of the research aims and hypotheses. This, in turn, may have led participants to exert demand characteristics, meaning that participants may respond in a manner that seeks to confirm the research hypotheses (Nichols $\&$ Maner, 2008). Research has shown that confidence in sentencing and the criminal justice system as a whole is higher among younger people (e.g., Jones \& Weatherburn, 20IO). As all participants were first year undergraduate psychology students, it is possible that this primarily young sample may have already had a high level of confidence in sentencing. Therefore, perhaps if pre-existing attitudes were measured and controlled for, the hypotheses may have been supported. Future research should aim to measure and control for these pre-existing attitudes, as well as recruit a sample across all age groups so that it is more representative of the general public.

Additionally, future research should aim to replicate this study with a larger sample size to determine whether the findings described in the current research are accurate, or whether other effects could be detected as a result of increased power. Nevertheless, we believe that the theoretical and practical contributions of the current research outweigh the sample size limitation. As there has been limited empirical evaluation of jury sentencing recommendations, it is important to foster a sense of evidence-based practice in this area. We believe that our research has provided a stepping stone to evaluate reforms in the legal field before implementation, thereby ensuring that resources are not wasted on ineffective reform.

\section{CONCLUSION}

The current research empirically evaluated the effectiveness of jury sentencing recommendations using elements of procedural justice theory. The results of the current research did not support the notion that jury sentencing recommendations provide an effective method of increasing public confidence in the courts as intended, however, limitations regarding preexisting attitudes as well as sample size have been discussed. Despite these limitations, the current study is one of the first known studies to empirically evaluate jury sentencing recommendations and is therefore an important stepping stone for future research in this area. This research provides unique theoretical contributions to the literature by applying the concepts of voice and the frustration effect to a novel context, as well as opening a new avenue of research into the effects of procedural justice on public 
confidence in the courts. Perhaps most importantly, the current research has highlighted the need for reforms and policy-making to be empirically evaluated prior to implementation, particularly in the criminal justice system.

\section{REFERENCES}

Adams, J. S. (1973). Inequality in social exchange. In L. Berkowitz (Ed.), Advances in Experimental Social Psychology (Vol 2.). New York: Academic Press.

Anderson, K., \& Saint, E. (2005). Japan's quasi-jury (saiban-in) law: An annotated translation of the act concerning participation of lay assessors in criminal trials. Asian-Pacific Law \& Policy Journal, 6(I), 233-283. Retrieved from http://www.hawaii.edu/aplpj/

Andrews, D., \& Pakula, M. (2013, February 4). Jury to have a say in sentencing under labor [Press Release]. Retrieved from https://www.viclabor.com.au/media-releases/juries-tohave-a-say-in-sentencing-under-labor/

Avery, D. R., \& Quińones, M. A. (2002). Disentangling the effects of voice: The incremental roles of opportunity, behavior, and instrumentality in predicting procedural fairness. The Journal of Applied Psychology, 87(I), 8I-86. doi: ILio37/oo2I-90io. 87.I.8I

Bean, C. (2005). Is there a crisis of trust in Australia? In S. Wilson, G. Meagher, R. Gibson, D. Denemark, \& M. Western (Eds.), Australian social attitudes: The first report (pp. I22-I40). Sydney: UNSW Press.

Beetham, D. (199I). The legitimation of power. Atlantic Highlands, NJ: Humanities International Press.

Boddy, N. (2013, February 15). Tomahawk killer gets life for grandmother's murder. The West Australian. Retrieved from http://au.news.yahoo.com/thewest/

Bradford, B. (20II). Voice, neutrality and respect: Use of victim support services, procedural fairness and confidence in the criminal justice system. Criminology \& Criminal Justice, II (4), 345-366. doi: Io.II77/I7488958II408832

Chaplin, R., Flatley, J., \& Smith, K. (20II). Crime in England and Wales 20IO/II. Retrieved from http://www.gov.uk/government/uploads/system/uploads/attachment_data/file/ II64I7/hosbioir.pdf

Cohen, R. L. (1985). Procedural justice and participation. Human Relations, 38(7), 643-663. doi: $10.1177 / 001872678503800703$

Criminal Code of Canada. (1985).

Department of Justice and Attorney-General. (2015). Applying for parole. Retrieved from http://www.justice.qld.gov.au/justice-services/courts-and-tribunals/going-to-court/ sentencing/the-parole-system

Earley, P. C., \& Lind, E. A. (1987). Procedural justice and participation in task selection: The role of control in mediating justice judgments. Journal of Personality and Social Psychology, 52(6), II48-II60. doi: Io.IO37/0022-35I4-52.6.II48

Enns, P. C. (2014). The public's punitiveness and its influence on mass incarceration in the United States. American Journal of Political Science, 58(3). doi: Io.III/ajps.I2098 
Folger, R. (1977). Distributive and procedural justice: Combined impact of voice and improvement on experienced inequity. Journal of Personality and Social Psychology, 35(2), I08-II9. doi: I0.1037/0022-35I4-35.2.108

Fondacaro, M. R., Brank, E. M., Stuart, J., Villanueva-Abraham, S., Luescher, J., \& McNatt, P. S. (2006). Identity orientation, voice, and judgments of procedural justice during late adolescence. Journal of Youth and Adolescence, 35(6), 987-997. doi: Io.Ioo7/ siog64-006-9035-8

Gibson, J. L. (1989). Understandings of justice: Institutional legitimacy, procedural justice, and political tolerance. Law \& Society Review, 23(3), 469-496. doi: 10.2307/3053830

Gibson, J. L., Caldeira, G. A., \& Spence, L. K. (2003). Measuring attitudes toward the United States Supreme Court. American Journal of Political Science, 47(2), 354-367. doi: I0.2307/3186144

Gleeson, M. (2004). Out of touch or out of reach? Retrieved from http://www.hcourt.gov.au/ assets/publications/speeches/former-justices/gleesoncj/cj_ozocto4.html

Gonzalez, C. M., \& Tyler, T. R. (2007). Why do people care about procedural fairness? The importance of membership monitoring. In K. Törnblom \& R. Vermunt (Eds.), Distributive and procedural justice: Research and social applications (pp. 9I-IIO). Hampshire, England: Ashgate Publishing Limited.

Goodman-Delahunty, J. (2010). Four ingredients: New recipes for procedural justice in Australian policing. Policing, 4(4), 403-4IO. doi: Io.Io93/police/paqo4I

Goodwin, C., \& Ross, I. (1992). Consumer responses to service failures: Influence of procedural and interactional fairness perceptions. Journal of Business Research, 25(2), I49-I63. doi: Io.IoI6/oI48-2963(92)90oI4-3

Granger, C. (1996). The criminal jury trial in Canada. Toronto: Carswell.

Green, D. A. (2006). Public opinion versus public judgment about crime: Correcting the "comedy of errors." British Journal of Criminology, 46(I), I3I-I54. doi: I0.I093/bjc/azio5o

Hayes, A. F. (2013). Introduction to mediation, moderation, and conditional process analysis: A regression-based approach. New York: Guilford Press.

Hirschman, A. O. (1970). Exit, voice, and loyalty. Cambridge, MA: Harvard University Press.

Hirschman, A. O. (1974). "Exit, voice, and loyalty": Further reflections and a survey of recent contributions. Social Science Information, I3(I), 7-26. doi: IO.II77/ 05390I847401300ior

Hoffman, M. B. (2003). The case for jury sentencing. Duke Law Journal, 52(5), 95I-IOIO. Retrieved from http://dlj.law.duke.edu

Homans, G. C. (196I). Social behaviour: Its elementary form. New York: Harcourt, Brace \& World.

Hora, P. (2013). Tough on crime is not smart on crime. Insight Magazine, Issue 8: Crime and Justice. Retrived from http://vcoss.org.au/documents/2013/o6/Insight.JudgePeggyHora. Final_.pdf

Horne, T. D. (1996). Some thoughts on bifurcated sentencing in non-capital felony cases in Virginia. University of Richmond Law Review, 30(2), 465. Retrieved from http:// lawreview.richmond.edu

Hough, M., Bradford, B., Jackson, J., \& Roberts, J. V. (2013). Attitudes to sentencing and trust in justice: Exploring trends from the crime survey for England and Wales. Retrieved from https:/www.gov.uk/government/uploads/system/uploads/attachment data/file/230I86/Attitudes_to_Sentencing_and_Trust_in_Justice_web_.pdf 
Hough, M., Jackson, J., Bradford, B., Myhill, A., \& Quinton, P. (20Io). Procedural justice, trust, and institutional legitimacy. Policing, 4(3), 203-2Io. doi: Io.I093/police/paq027

Hough, M., \& Roberts, J. V. (2004). Public confidence in justice: An international review. Retrieved from http://www.icpr.org.uk/media/32918/public confidence in justice international review.pdf

Indermaur, D. (2008). Dealing the public in: Challenges for a transparent and accountable sentencing policy. In A. Freiberg \& K. Gelb (Eds.), Penal populism, sentencing councils and sentencing policy (pp. 45-67). Sydney: Hawkins Press.

Indermaur, D., \& Roberts, L. (2009, November). Confidence in the criminal justice system: Trends and issues in crime and criminal justice No. 387. Retrieved from http://www.aic. gov.au/documents/D/6/8/\%7bD68CD7EA-536A-4025-A8Co-A5BADF59A6AC\%7 dtandi387.pdf

Iontcheva, J. (2003). Jury sentencing as democratic practice. Virginia Law Review, 89(2), 3II-383. doi: $10.2307 / 3202435$

Ipsos-Reid. (2002). Public views on information sharing in the CJS: Final report. Ottawa, Canada: Solicitor General.

Jones, C., \& Weatherburn, D. (2010). Public confidence in the NSW criminal justice system: A survey of the NSW public. The Australian and New Zealand Journal of Criminology, 43(3), 506-525. doi: I0.1375/acri.43.3.506

Judicial Conference of Australia. (2007). Judge for yourself: A guide to sentencing in Australia. Retrieved from https://www.sentencingcouncil.vic.gov.au/publications/judge-foryourself-a-guide-to-sentencing-in-australia

King, N. J., \& Noble, R. L. (2004). Felony jury sentencing in practice: A three-state study. Vanderbilt Law Review, 57(3), 883-962. Retrieved from http://www.vanderbiltlawreview. org

LaTour, S. (1978). Determinants of participant and observer satisfaction with adversary and inquisitorial modes of adjudication. Journal of Personality and Social Psychology, 36(I2), I53I-I545. doi: IO.I037/0022-35I4.36.I2.I53I

Lethbridge, G. (2013). Tough on crime means doing more time. Retrieved from http:// www.findlaw.com.au/articles/89i/tough-on-crime-means-doing-more-time.aspx

Lind, E. A., Kurtz, S., Musante, L., Walker, L., \& Thibaut, J. W. (1980). Procedure and outcome effects on reactions to adjudicated resolution of conflicts of interest. Journal of Personality and Social Psychology, 39(4), 643-653. doi: I0.I037/oo22-35I4-39.4.643

Lind, E. A., \& Lissak, R. I. (1985). Apparent impropriety and procedural fairness judgments. Journal of Experimental Social Psychology, 2I(I), I9-29. doi: I0.I0I6/0022-IO3I(85)90003-4

MacCoun, R. J., \& Tyler, T. R. (1988). The basis of citizens' perceptions of the criminal jury: Procedural fairness, accuracy, and efficiency. Law and Human Behavior, I2(3), 333-352.

Mackenzie, G., Spiranovic, C., Warner, K., Stobbs, N., Gelb, K., Indermaur, D., Bouhours, T. (20I2). Sentencing and public confidence: Results from a national Australian survey on public opinions towards sentencing. Australian \& New Zealand Journal of Criminology, 45(I), 45-65. doi: Io.II77/00048658II431328

Mann, T., \& Blunden, A. (20I0). Australian law dictionary. Melbourne, Australia: Oxford University Press.

Maruna, S., \& King, A. (2004). Public opinion and community penalties. In A. Bottoms, S. Rex \& G. Robinson (Eds.), Alternatives to prison: Options for an insecure society (pp. 83IO2). Devon, England: Willan Publishing. 
Mazerolle, L., Antrobus, E., Bennett, S., \& Tyler, T. R. (2013). Shaping citizen perceptions of police legitimacy: A randomized field trial of procedural justice. Criminology, 5I(I), 33-63. doi: Io.IIII/j.I745-9I25.20I2.00289.x

Mazerolle, L., Bennett, S., Antrobus, E., \& Eggins, E. (2012). Procedural justice, routine encounters and citizen perceptions of police: Main findings from the Queensland Community Engagement Trial (QCET). Journal of Experimental Criminology, 8(4), 343-367. doi: Io.IOO7/sII292-0I2-9160-I

McKee, J. Y. (200I). Criminal justice systems in Europe and North America: France. Report of the European Institute for Crime Prevention and Control, Affiliated with the United Nations. Helsinki: HEUNI.

Moore, M. H. (1997). Legitimizing criminal justice policies and practices. FBI Law Enforcement Bulletin 66(Io), I4-2I. Retrieved from https://leb.fbi.gov/

Murphy, K., \& Cherney, A. (20II). Fostering cooperation with the police: How do ethnic minorities in Australia respond to procedural justice-based policing? Australia and New Zealand Journal of Criminology, 44(2), 235-257. doi: I0.II77/00048658II405260

New South Wales Law Reform Commission (NSWLRC). (2006). Issue paper 27: Sentencing and juries. Retrieved from http://www.lawreform.justice.nsw.gov.au/Documents/ Publications/Other-Publications/Issues-Papers/IP27.pdf

Nichols, A. L., \& Maner, J. K. (2008). The good-subject effect: Investigating participant demand characteristics. The Journal of General Psychology, I35(2), I5I-66. doi: I0.3200/ genp.I35.2.I5I-I66

O’Brien, K., Goodman-Delahunty, J., Clough, J., \& Pratley, J. (2008). Factors affecting juror satisfaction and confidence in New South Wales, Victoria, and South Australia. Trends and Issues in Crime and Criminal Justice No. 354. Canberra: Australian Institute of Criminology.

Ostrom, B. J., Kauder, N. B., \& Kuban, G. B. (1996). Examining the work of state courts, 1995: A national perspective from the court statistics project. Retrieved from http:// cdmi65oi.contentdm.oclc.org/cdm/ref/collection/ctadmin/id/22

Potter, P. W. (2006). Procedural justice and voice effects. Journal of Organizational Culture, Communication and Conflict, IO(I), 33-6I.

Roberts, J. V. (2007). Public confidence in criminal justice in Canada: A comparative and contextual analysis. Canadian Journal of Criminology and Criminal Justice, 49(2), I53I84. doi: I0.3138/rn84-237I-2482-mro6

Roberts, L., \& Indermaur, D. (2009). What Australians think about crime and justice: Results from the 2007 survey of social attitudes. Retrieved from http://www.aic.gov.au/media_ library/publications/rpp/ıoi/rppioI.pdf

Robinson, P. H., \& Darley, J. M. (1997). The utility of desert. Northwestern University Law Review, 9I(2), 453-499. Retrieved from http://www.northwesternlawreview.org/

Rottman, D. B. (2005). Trust and confidence in the California courts. Retrieved from http:// www.courts.ca.gov/documents/4_37pubtrusti.pdf

Sentencing Advisory Council. (20II). Minimum standard non-parole periods. Retrieved from http://www.justice.qld.gov.au/__data/assets/pdf_file/oo2o/155702/minimum-snpppaper.pdf

Shchepetova, A. (2013). Inquisitorial vs. adversarial system and the right to be silent. Retrieved from https://editorialexpress.com/cgi-bin/conference/download.cgi?db_name=IIOC 2013\&paper_id=602 
Smith, B. L., \& Stevens, E. H. (1984). Sentence disparity and the judge-jury sentencing debate: An analysis of robbery sentences in six southern states. Criminal Justice Review, 9(I), I-7. doi: Io.II77/o73401688400900IoI

Sourcebook of Criminal Justice Statistics. (2012). Reported confidence in the criminal justice system. Retrieved from http://www.albany.edu/sourcebook/pdf/t2II2oI2.pdf

Spigelman, J. J. (2005). A new way to sentence for serious crime. Judicial Officers' Bulletin, $I 7(\mathrm{I}), \mathrm{I}-4$. Retrieved from http://www.judcom.nsw.gov.au/publications/bulletins-andjournals

St Amand, M. D., \& Zamble, E. (200I). Impact of information about sentencing decisions on public attitudes toward the criminal justice system. Law and Human Behavior, 25(5), 515-528. doi: IO.IO23/a:IOI2844932754

Statistics Canada. (2003). The confidence Canadians have in various institutions. Retrieved from http://www.statcan.gc.ca/pub/89-598-x/20030oi/figures/4067758-eng.htm

Sunshine, J., \& Tyler, T. R. (2003). The role of procedural justice and legitimacy in shaping public support for policing. Law \& Society Review, 37(3), 513-548. doi: Io.IIII/I540-5893. 3703002

Sunstein, C. R. (2002). Punitive damages: How juries decide. Chicago: University of Chicago Press.

Thibaut, J. W., \& Walker, L. (1975). Procedural justice: A psychological analysis. Hillsdale, NJ: Lawrence Erlbaum Associates.

Tyler, T. R. (1990). Why people obey the law: Procedural justice, legitimacy, and compliance. New Haven, CT: Yale University Press.

Tyler, T. R. (200I). Public trust and confidence in legal authorities: What do majority and minority group members want from the law and legal institutions? Behavioral Sciences \& the Law, I9(2), 215-235. doi: I0.1002/bsl.438

Tyler, T. R. (2003). Procedural justice, legitimacy, and the effective rule of law. In M. Tonry (Ed.), Crime and justice (pp. 283-357). Chicago: The University of Chicago Press.

Tyler, T. R. (2007). Procedural justice and the courts. Court Review: The Journal of the American Judges Association, 44(I/2), 25-3I. Retrieved from http://aja.ncsc.dni.us/htdocs/ publications-courtreview.htm

Tyler, T. R., \& Huo, Y. J. (2002). Trust in the law: Encouraging public cooperation with the police and courts. New York: Russell-Sage Foundation.

Tyler, T. R., \& Lind, E. A. (1988). The social psychology of procedural justice. New York: Plenum Press.

Tyler, T. R., \& McGraw, K. M. (1986). Ideology and the interpretation of personal experience: Procedural justice and political quiescence. The Journal of Social Issues, 42(2), II5-I28. doi: IO.IIII/j.I540-4560.I986.tboo228.x

Tyler, T. R., Rasinski, K. A., \& Spodick, N. (1985). Influence of voice on satisfaction with leaders: Exploring the meaning of process control. Journal of Personality and Social Psychology, 48(I), 72-8I. doi: Io.I037/o022-35I4.48.I.72

Ulbig, S. G. (2008). Voice is not enough. Public Opinion Quarterly, 72(3), 523-539. doi: Io. I093/poq/nfnozo

Vidmar, N. (1999). The Canadian criminal jury: Searching for a middle ground. Law and Contemporary Problems, 62(2), I4I-I72. Retrieved from http://lcp.law.duke.edu

Webster, C. W. (1960). Jury sentencing—grab-bag justice. Southwestern Law Journal, I4(I), 22I. 
Weninger, R. A. (1994). Jury sentencing in noncapital cases: A case study of El Paso County, Texas. Washington University Journal of Urban and Contemporary Law, 45(3), 3-40. Retrieved from http://law.wustl.edu/journal/

Wright, R. F. (1999). Rules for sentencing revolutions (Book review). The Yale Law Journal, IO8(6), I355-I387. doi: I0.2307/797329

\section{APPENDIX A}

\section{Compliance with Ethical Standards}

\section{Funding}

The authors report none.

\section{Ethical Approval}

Ethical approval (clearance number I3-PSYCH-4-IO3-JJ) was granted by the School of Psychology Ethics Committee at the University of Queensland.

\section{Informed Consent}

Consent for this research was fully informed and voluntary. Participants were informed that their responses would be anonymous, as no identifying information would be collected from them. Participants were able to withdraw from the study at any time.

\section{Conflicts of Interest}

The authors report no conflicts of interest.

\section{APPENDIX B: MEASURES}

Confidence in sentencing (case):

- In this case, the individual Judge was the best person to choose an appropriate sentence.

- In this case, I am satisfied with the decision that the court made.

- In this case, the Judge was in touch with what ordinary people think.

- In this case, how confident are you that the penalty or punishment given to the offender was appropriate?

- In this case, how confident are you that the Court was effective at giving a punishment which fit the crime?

- Based on this case, how confident are you in the Courts? 
Confidence in sentencing (general):

- The individual Judge is the best person to choose an appropriate sentence for each case.

- I am satisfied with the decisions that the courts make.

- I have confidence that judges impose an appropriate sentence most of the time.

- Judges are in touch with what ordinary people think.

- How confident are you that penalties or punishment given to offenders are appropriate?

- How confident are you that the courts are effective at giving punishments which fit the crime?

- How confident are you generally in the courts and legal system?

Procedural fairness (case):

- In this case, how fair was the procedure used to determine the defendant's minimum non-parole period.

Procedural fairness (general):

- The Courts give victims and witnesses the support they need.

- The Courts take into account the views of witnesses and victims.

- The Courts take into account the views of the community.

- The Courts achieve the correct balance between the rights of the offender and the rights of the victim when handing out sentences.

- The Courts take into account the circumstances surrounding the crime.

- The Courts always try to be fair when making decisions.

- The Courts treat people with dignity and respect.

Legitimacy (case):

- In this case, how legitimate was the process used to determine the defendant's minimum non-parole period.

Legitimacy (general):

- If the Courts started making a lot of decisions that most people would disagree with, it might be better to do away with the Courts altogether.

- The right of the Courts to decide certain types of controversial issues should be reduced. 
- Judges of the Courts who consistently make decisions at odds with what the majority of people want should be removed from their position as Judge.

- The Courts ought to be made less independent so that they listen a lot more to what people want.

- The Courts get too mixed up in politics.

- The decisions of the Courts represent those of people in power and not the values of people like me.

- The Courts do not always act in a way that protects my interests. 